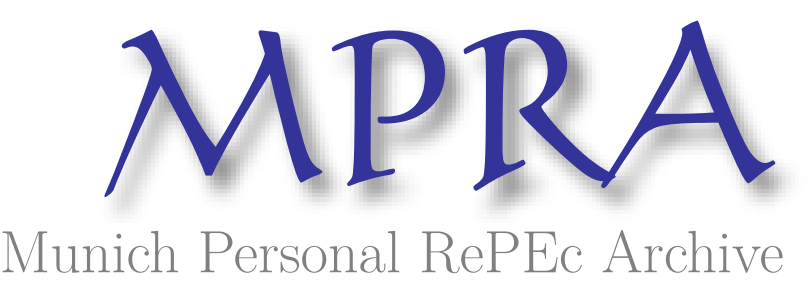

\title{
Land Degradation and Trade Liberalization: An Indian Perspective
}

Pohit, Sanjib

NISTADS-CSIR

2013

Online at https://mpra.ub.uni-muenchen.de/44496/

MPRA Paper No. 44496, posted 20 Feb 2013 13:12 UTC 


\title{
Land Degradation and Trade Liberalization: An Indian Perspective
}

\author{
Sanjib Pohit ${ }^{1}$ \\ National Council of \\ Applied Economic Research \\ 11 Indraprastha Estate \\ New Delhi 110002 INDIA \\ Email: spohit@ncaer.org; spohit@gmail.com
}

\begin{abstract}
This paper makes an attempt to use GTAP model to understand the interplay between the agricultural trade liberalization and land degradation in India. Like any other developing country, soil erosion happens to be one of the principal environmental problems caused by agricultural production in India. In this paper, our attempt is to simulate the on-site productivity impacts of erosion, along with standard intersectoral and inter-regional economic effects of trade liberalization.
\end{abstract}

The deeper and fuller agricultural trade liberalization opens up opportunities for India's agriculture. Our result indicates that paddy, wheat, and other agriculture are the sectors in India where production would expand following liberalisation while there would be a fall in production in cereal grain sector and livestock sector. Overall, there is a small increase in India's welfare to the tune of US \$ 360 millions. While India's agricultural expands due to opening up of opportunities, soil degradation increases with increased use of land. To what extent, the above result would change if we incorporate land degradation feedback mechanism in our analysis? Our results indicates that agricultural trade liberalisation reduces land productivity, but the effects are weak to negate the benefits of India's welfare from agricultural trade liberalisation.

Key Word: Land Degradation, Trade Liberalization

JEL: C680, Q560

\footnotetext{
${ }^{1}$ The views expressed in this paper are of the author and not of the institute to which he belongs. A part of the work was completed under the SANEI funded project entitled Climate Change \& Agriculture: A CGE Modelling Exercise, a study of which self was the Principal Investigator.
} 


\section{Introduction.}

Land degradation may have significant adverse effects, particularly in developing countries (Scherr and Yadav, 1996; Rosegrant and Ringler, 1997). The few in-depth analysis of soil erosion that has been done in temperate areas indicates that the consequences are not large for aggregate agricultural productivity, although they are a concern for susceptible soils. Several studies have concluded that erosion in the United States may cause cereal yields to be 3-10 percent less at the end of the next century than what would otherwise be achieved. The problem is substantially greater in tropical developing countries, where soils, rainfall, and agricultural practices are more conducive to erosion and where many reports have found rates of soil loss well above the natural rate of soil formation. For instance, average erosion rates in USA are estimated at about 0.7 tons of soil/hectare/year. By contrast, the overall erosion rates in tropical countries is to the tune of about 6-12 tons of soil/hectare/year. The high erosion rates are mainly due to the level and intensity of tropical rainfall, and the loss of ground cover on steep terrain. Countries with fragile tropical land are particularly problematic, and rural poverty in developing countries may force people with no other options to exploit available resources beyond their sustainable capacity. It is therefore important to attempt to model these production feedbacks on land productivity in India.

A large and growing population has placed a great deal of stress on the topsoil resources of the Indian-Subcontinent. Much of the land used for agriculture in the Indian Subcontinent is of a very marginal nature. This, combined with the intensive nature of the agricultural practices of this region, has placed its soil resources face a constant danger of depletion. Currently, the heavy application of fertilizers is required to maintain basic productive capacity. Some estimates have placed India's use of arable land resources at $120 \%$, which means that fully one the land currently under cultivation is unable to sustain agriculture in the long term.

Several factors contribute to the growing stress that has been placed on this regional agricultural land. Rapid urban and industrial development, deforestation, inadequate soil conservation, the cultivation of steep slopes and overgrazing have all had a devastating impact. Over 110 million hectares of agricultural land in India alone are acknowledged to be significantly degraded, with that number growing every year.

Many of the problems that face agriculturalists in South Asia in general and India in particular, are closely related to population growth. Average life expectancy in this region has doubled in the last fifty years, and this has resulted in a population explosion. Rapid population growth has disrupted traditional systems of land tenure and inheritance, leaving 
many landless. Many of these have extended their agricultural activities onto increasingly marginal land, which has contributed to erosion problems and required unsustainable levels of irrigation. Other has flocked to the growing slums that surround major cities, slums which are built atop some of the region's best agricultural land. For those who have remained on the land, the imperative to produce more food on shrinking plots, either for personal consumption or as a source of cash income, has demanded the adoption if intensive agricultural techniques that often have dire consequences for the soil and adjacent rivers and aquifers.

Much of the land presently under cultivation was deemed until recently suitable only for animal husbandry. This has had two consequences. First, growing food crops on such land has required the development of intensive irrigation programs. Second, it has pushed grazers onto more marginal land where their herds have damaged fragile ecosystems and where grazing must often be supplemented with fodder cut in the forest. Both have contributed to a growing problem of erosion. According to the United Nations Food and Agriculture Organization (FAO) wind and water erosion have badly degraded of as much as 27 percent of India's soil. In the mountainous north of India and Nepal, erosion has been particularly severe, and it has almost completely wiped-out the region's agricultural capacity.

Irrigation is another factor in soil degradation. Over use of irrigation can lead to mineral build-up in the topsoil, and salinisation has become a significant threat to the region's agricultural capacity. In the 1980s India, together with its neighbours Pakistan and China, accounted for over fifty percent of the world's land damaged by salinisation.

As erosion, topsoil loss and salinisation have diminished agricultural capacity, South Asian farmers have turned increasingly to chemical fertilizers and pesticides to improve crops and to maximize yields. Although this has produced a short term increase in yields, it has permitted overcropping, which has reduced the available organic matter in the soil. Humus loss reduces the ability of the soil to retain water, speeding precipitation runoff, increasing the probability of flooding and water erosion, and making the region more vulnerable to drought.

Finally, local food crops are facing pressure from export crops. Although the region faces chronic food shortages, increasingly marginal land continues to be used for cash crops. This includes the development of teas plantations in the fragile mountain regions of the north. As further international trade is demanded under structural adjustment programs, the importance of cash crops and food crop exports is expected to grow. This development is expected to force more food production onto marginal areas, which will amplify existing problems, especially as relates to erosion.

However there are no reliable information available on type, intensity and severity of land degradation for India. Some estimates on productivity loss due to soil erosion are also available through Bansil and FAO cited in the study by Brandon et al. (1995). As per this, the 
total annual loss in productivity of major crops due to soil erosion is estimated as 7.2 million tones.

\section{Insert Table 1}

A rough estimate of soil erosion and sedimentation for India reveals that about 5300 million tonnes of top soil are eroded annually and $24 \%$ of this quantity is carried by rivers as sediments and deposited in the sea, and nearly $10 \%$ is deposited in reservoirs reducing their storage capacity by $2 \%$. As for water logging and salination, the available estimates show that canal command area constitutes $48 \%$ of the total water logged area, and $45 \%$ of the total salt affected area in India. In fact for a few states like Andhra Pradesh, Tamil Nadu, Orissa, Punjab and Gujarat, canal irrigated area occupies $100 \%$ of the total water logged area.

A recent pioneering study sponsored by three United Nations agencies (FAO, UNDP and UNEP) estimated the severity and costs of land degradation in South Asia. Its finding was that the countries (India, Pakistan, Bangladesh, Iran, Afghanistan, Nepal, Sri Lanka, Bhutan) are losing at least US $\$ 10$ billion annually as a result of losses resulting from land degradation. This was equivalent to $2 \%$ of the region's Gross Domestic Product, or $7 \%$ of the value of its agricultural output. Yet this figure is still an underestimate, because it measures only the onsite effects leaving out off-site costs. The interesting part of the study is its assessment of the economic costs of land degradation. Total on-site annual losses were estimated at US\$9.8 to 11 billion a year. The breakdown according to types of land degradation was: water erosion US $\$ 5.4$ billion; wind erosion US $\$ 1.8$ billion; fertility decline US $\$ 0.6$ to 1.2 billion; water logging US $\$ 0.5$ billion and salinisation US $\$ 1.5$ billion.

This paper makes an attempt to use the GTAP model to model the effects of land degradation for Indian economy. We simulate on-site productivity impacts along with the more standard intersectoral and interregional economic effects of Doha rounds of negotiation. The contribution of the paper is to quantify the welfare implications of trade policy changes for a large developing country, where soil erosion occurs and land productivity is reduced.

\section{Modelling land degradation in India}

Computable general equilibrium (CGE) models can be used to simulate and analyse policy changes having economy-wide impacts. Many policy reforms such as trade liberalization -even if directed to just one sector - affect other sectors of the economy. These interactions can only be captured in a multi-sectoral model. CGE models have tight theoretical specifications and unlike econometric models, can provide insights into changes for which there is no historical experience (Dixon and Paramenter, 1994). This makes them particularly attractive for modelling prospective policy changes and their environmental effects. 
The environmental links of agricultural production are two-way. Agricultural production affects environmental quality and environmental quality affects agricultural production. There are many interrelated variables and feedback effects, and measurement of even the major environmental effects is not easy. As farmers increase their production, they tend to generate more erosion. The erosion damage can cause on-site productivity losses or off-site environmental damage. Farmers may respond to the on-site productivity effects (Barrett, 1991), but are unlikely to take the non-marketed off-site impacts of their activities into account when they make decisions if there are no incentives to do so.

In this paper, we have made an attempt to model the on-site productivity effects of land degradation through a modification of the standard GTAP model by enabling the land to shift between agriculture and forestry. As land quality deteriorates due to erosion, additional units of land (and other primary factors) are required to sustain the same level of output. In this way, we mimic the deterioration in land quality and productivity under erosion through the use of this feedback parameter.

\subsection{Transformation of Land between sectors \& On-site Productivity effects}

In the GTAP model, land is an imperfectly mobile factors of production with the mobility described by a constant elasticity of transformation (CET) function (Hertel and Tsigas, 1997). The CET revenue function is analogous to the constant elasticity of substitution (CES) cost function, but with the Allen partial elasticity of substitution less than zero for CET function. This restricts mobility and enables productivity differences between land used in different farm sectors, with land measured in productivity units rather than hectares (Darwin et al, 1995). As the elasticity of transformation becomes larger in absolute values, the degree of sluggishness decreases and land becomes a relatively mobile factor with similar rents across sectors. In our modelling exercise, we have retained the standard GTAP elasticity of transformation function for all land-using sectors including forestry.

Production feedback effects are modelled to capture the adverse impacts of no-site soil erosion on land productivity. We have attempted to capture the effects of land degradation in our base model by modifying the model through use of a land quality shifter parameter, $\mathrm{FB}_{\mathrm{f}}^{\mathrm{j}}$. As land quality deteriorates due to erosion, additional units of land (and other primary factors) are required to sustain the same level of output. In this way, we mimic the deterioration in land quality and productivity under erosion through the use of this feedback parameter.

Let us now derive sector $\mathrm{j}$ 's demand for primary factors in the presence of erosion. ${ }^{2}$ There are five primary factors of production in the GTAP version 6 database: land, unskilled

\footnotetext{
${ }^{2}$ The derivation follow the route adopted by Strutt (1998).
} 
labour, skilled labour, capital and natural resources. These primary factors combine according to CES production technology, which is used to describe substitution possibilities between units of primary factors in sector $\mathrm{j} .3$ The resulting effective primary factor input for sector $\mathrm{j}$ is then combined with intermediate inputs to form the production capability of sector $j$.

Given the prices of primary factor $\mathrm{f}$ in sector $\mathrm{j}\left(\mathrm{P}_{\mathrm{f}}^{\mathrm{j}}\right)$, profit maximising producers choose the least cost combination of primary factor inputs of type $\mathrm{f}\left(\mathrm{X}_{\mathrm{f}}^{\mathrm{j}}\right)$ necessary to sustain a given level of production $\left(\mathrm{Z}^{\mathrm{j}}\right)$. Producers minimise:

$\sum_{f=1}^{5} \bar{P}_{f}^{j} x_{f}^{j} \quad j=1, \ldots, n$

subject to a CES production function

$Z^{j}=A\left[\sum_{f=1}^{5} \delta_{f} \bar{X}_{i}^{-\rho}\right]^{-\frac{1}{\rho}}$

Where,

$\overline{X_{f}^{j}}=\frac{X_{f}^{j}}{F B_{f}^{j}} \quad, \bar{P}_{f}^{j}=F B_{f}^{j} P_{f}^{j}$

A and $\delta_{f}$ are positive parameters with $\sum_{f=1}^{5} \delta_{f}=1 . \rho$ is a parameter greater than or equal to -1 ;

as it approaches zero, it approaches a Cobb-Douglas form. $\overline{X_{f}^{j}}$ is the effective land input

(Dixon et al., 1992, pp. 125-6).

The lagrangian function is:

$L=\sum_{f=1}^{5} \bar{P}_{f}^{j} \bar{X}_{f}^{j}+\Lambda\left(Z^{j}-C E S_{F=1 . .5}\left(\bar{X}_{f}^{j}\right)\right)$

where $\Lambda$ is the Lagrange multiplier. The first order conditions for the cost minimising problems are:

$$
\begin{aligned}
& \bar{P}_{f}^{j}=\Lambda A\left[\sum_{f=1}^{5} \delta_{i} \bar{X}_{i}^{-\rho}\right]^{\frac{-(1+\rho)}{\rho}} \delta_{g} \bar{X}_{g}^{-(1+\rho)} \\
& L_{\wedge}=Z^{j}-C E S_{f=1.5}\left(\overline{X_{f}^{j}}\right)=0
\end{aligned}
$$

\footnotetext{
${ }^{3}$ It should be pointed out that not all primary inputs are used for production in any sector. Two types of labours, capital are used in all the sectors, land is one of the inputs in all the five agricultural sectors including livestock, natural resources is used in only two sectors namely livestock and mineral.
} 
i.e. $Z^{j}=A\left[\sum_{f=1}^{5} \delta_{i} \bar{X}_{i}^{-\rho}\right]^{\frac{-1}{\rho}}$

These conditions are solved to determine the primary factor demand equation, which is expressed in linear percentage change form as (Dixon et al. 1992, pp. 125)

$\overline{x_{f}^{j}}=z^{j}-\sigma_{f}^{j}\left(\bar{p}_{f}^{j}-\sum_{f=1}^{5} S_{f}^{j} \bar{p}_{f}^{j}\right)$

Lower case letters are used to indicate the percentage change in the corresponding upper case varaibles. Applying the percentage change forms of the two equations in (3), we find the primary factor demand:

$x_{f}^{j}=z^{j}+f b_{f}^{j}-\sigma_{f}^{j}\left(p_{f}^{j}-\sum_{f=1}^{5} S_{f}^{j} p_{f}^{j}\right)-\sigma_{f}^{j}\left(f b_{f}^{j}-\sum_{f=1}^{5} S_{f}^{j} f b_{f}^{j}\right)$

where

$$
\begin{aligned}
& \sigma_{f}^{j}=1 /\left(1-h_{f}^{j}\right) \\
& s_{f}^{j}=\delta_{k} X_{k}^{-\rho} /\left(\sum_{i} \delta_{i} X_{i}^{-\rho}\right)
\end{aligned}
$$

and

$x_{f}^{j}=$ demand for primary factor $f$ by sector $j$

$z^{j}=$ activity level in sector $j$

$f b_{f}^{j}=$ primary factor- $f$-augmenting feedback

$\sigma_{f}^{j}=$ elasticity of substitution between primary factors in sector $j$

$p_{f}^{j}=$ unit price or rental rate for primary factors used by sector $j$

$S_{f}^{j}=$ share of primary factor cost in sector $j$ accounted for by the cost of primary factor $f$.

Equation (5) related each sector's demand for primary factors to the overall activity level in the sector, to the costs of different types of primary factors, and to the feedback variable. Equation (5) indicates that if land degradation causes a $1 \%$ increase in the land specific feedback variable $\left(f b_{f}^{j}\right)$, then the requirement of land by sector $j$ increases by

( $\left.1-\sigma^{j}\left(1-S_{f}^{j}\right)\right)$ in order to sustain the given level of activity, assuming of course that the factor prices are constant. Such a reduction in the quality of land will also induce substitution away from land towards the other two primary factors. 
The effects of the feedback variable outlined above can be incorporated in GTAP model by suitable modification. In the GATP model, the equivalent of equation (5) appears as two types of equations. The first describes substitution among within a nest. Its form follows directly from the CES form of production function. The second type of equation is the composite price equation, which determines the unit cost for the composite good produced by that branch (Hertel and Tsigas, 1997). We have modified both of these equations to incorporate feedback effects.

For India, we assume that the adverse effects of on-site soil erosion cause a reduction in land productivity in the agricultural sectors. The past study (Repetto et al 1989) indicates the erosion sensitive crop sector (for example, grain sector) exhibits a $6.8 \%$ reduction in land productivity while erosion less sensitive crops exhibits a $4.4 \%$ reduction in land productivity. Our other agricultural sector is mix of several crops. We assume that $50 \%$ of the crops are erosion-sensitive, which lead to a $5.55 \%$ reduction in land productivity for the other agricultural sector. No adverse productivity effects are assumed for forestry sector.

\section{Agricultural Trade Liberalisation: Implication on Land Degradation}

Liberalisation of global agriculture-a key element of the globalisation process-has been an issue that has been pursued by the developing countries in the recent global trade meets. However as the above discussion points out, if agricultural trade liberalisation leads to increasing use of agricultural land, it has its cost in the form of land degradation, which may diminish the gains (if any) from agricultural trade liberalisation. To quantify the impact, we have run two simulations. In the first simulation, we have attempted to analyse the implication of agricultural trade liberalisation on India. This has been modelled without incorporating the land degradation feedback mechanism in our model. In the second simulation, we examine to what extent our results changed when we incorporate the land degradation feedback mechanism in our model.

The complete GTAP model is a multi-regional applied general equilibrium (AGE) model that captures world economic activity in 57 different industries of 87 regions (version 6 of the database). However for our analysis, we have used an aggregated version of this database with 10 sectors and 10 regions. The sectors and the regions are shown in Table 2.

\section{Insert Table 2}

The structure of GTAP model is now widely known. However, for readers who are not familiar with the model structure, it would be a good idea to provide a brief description of the model structure. The theory behind the GTAP model is similar 
to that of other standard, multi-regional AGE model. The underlying equation system of GTAP includes two different kinds of equations. One part covers the accounting relationships, which ensure that receipts and expenditures of every agent in our model economy are balanced. The other part of the equation system consists of behavioral equations, which based upon microeconomic theory. These equations specify the behavior of optimizing agents in the economy, such as demand functions.

The GTAP model employs the so-called Armington assumption in the trading sector, which provides the possibility to distinguish imports by their origin, and explains intra-industry trade of similar products. Thus, imported commodities are assumed to be separable from domestically produced goods and combined in an additional nest in the production tree. The elasticity of substitution in this input nest is equal across all uses. Under these circumstances, the firms decide first on the sourcing of their imports and based on the composite import price, they then determine the optimal mix of imported and domestic goods.

The market structure in all sectors of the model is assumed to be perfect competition. This is definitely a weakness of the model. Commodity supplies are based on single-output production functions. Substitution between inputs is modeled with two-level nested production functions. Demand for land, labor, and capital are based on Constant elasticity of Substitution (CES) functions. International trade clears commodity markets, with each commodity being differentiated by its place of origin. Trade polices operate as ad valorem distortions, which in addition to transportation costs, form a wedge between domestic and world prices.

Households maximize utility derived from market goods (i.e. consumption and savings) subject to regional income, which consists of primary factor payments and net tax collections. Regional production of new capital goods is financed by domestic savings and net capital inflow. The price index for international capital is the numeraire. The model is implemented and solved using GEMPACK.

\section{Key issues in Agricultural Trade Liberalisation}

Liberalisation of global agriculture - a key element of the globalization process - is governed by the Agreement on Agriculture (AoA). The three main components of AoA, which include import market access, export competition and domestic support for agriculture, 
aim at reducing levels of protection and support in the sector and hence, distortions in the global economy. Towards guaranteeing freer market access and fair export competition for agricultural commodities, the Uruguay Round measures aim at phasing down of tariff barriers, reducing export subsidies, and setting certain guidelines for domestic support policies4.

Rolling back of some tariff and non-tariff barriers and the reduction in production and export subsidies to developed country agriculture, which have restricted global agricultural trade, would raise world prices of agricultural products and give direct incentives to developing country agriculture. This would necessarily result in export surplus in developing countries (Gulati and Sharma 1995) and enhance global welfare. However, trade preferences given to developing countries are often found to erode, lead to the decline of preferential position enjoyed by developing countries against other suppliers and result in some trade losses. Further, such liberalisation can have a dampening effect on the domestic economy and overall welfare in terms of rising wage goods prices and inflation. Storm (1997), in terms of dynamic general equilibrium estimates, show that reforms in the agricultural sector in India can be distributionally regressive unless accompanied by public irrigation investment and institutional changes.

In agriculture, while the developing countries have liberalised to a great extent and sometimes the actual tariff rates are well below the bound levels, significant barriers to trade exist in developed countries in terms of high tariffs and non-tariff barriers and large-scale production and exports subsidy. In such cases, further lowering of tariff rates by developing countries may not yield results in terms of global welfare since most of these countries have fulfilled much of their commitments stipulated in the URAA.

However, in the post-UR regime, the actual agricultural trade remained much lower than the predicted level of imports of the Michigan model due to implementation problems of the Industrialised countries. The main players of the WTO negotiations such as the EU, Japan and the USA, have continued with almost similar levels of agricultural protection which existed before the UR. There is only change in the nature of subsidy delivering system. It may be argued that if export and production subsidies in these countries can be significantly reduced, it would not only improve global welfare but also support the endeavour of developing countries in promoting their global agricultural trade. The extent of response to agricultural trade liberalisation will depend on substantial support resulting from new technology and restructuring. However, agricultural product importing (net) nations would

\footnotetext{
4 Export subsidies, as envisaged in the UR, include payments in kind, exports from stocks with financial assistance, producer finance export subsidies, export marketing cost subsidies, transportation subsidies and subsidies incorporated in to exports. However, certain green box policies are found to be minimally trade-distorting and can be used for domestic support.
} 
face a deteriorating terms of trade. All these implications of the URAA have opened up differences in interests between countries. The key issue is thus the estimation of gains, especially for developed countries, from liberalisation of developed country agriculture. The realisation of such estimated gains will again depend upon "safeguards" provided against disruption of import markets from low landed-prices of agricultural imports and "sanitary and phytosanitary measures" that govern agricultural trade.

We have used our base model (10-sector, 10-region, 5 factors GTAP-based CGE model) for capturing the impact of agricultural trade liberalisation.

It is believed that comprehensive and deeper trade liberalisation in agriculture would bring sizeable welfare gains to the world economy. This happens because when protection is reduced, economic activity gets realign (interregional and intersectoral shifts) along the line of comparative advantage, making production more efficient in all the countries. For modelling purpose, we assume that all the countries/region (except ROW) of our model economy abolish import tariff completely (100\% removal) on all agricultural commodities, viz. 5 in our case, namely paddy (PDR), wheat (WHT), cereal grains (GRO), other agriculture $(\mathrm{OAG})$, livestock and forestry (LIF). The results of this simulation supports that agricultural liberalisation is welfare improving. It is found that the agricultural trade liberalisation would not only improve welfare of most of the economies in our model economy, but India seems to be a larger gainer (Table 3). The rest of the South Asian economy (aggregate of Bangladesh, Nepal, Pakistan, Bhutan, Maldives and Sri Lanka) is also likely to gain, albeit small, from the process of liberalisation. It is interesting to note that many of the developing countries/region in our model stands to gain from agricultural liberalisation. On the other hand, some of the developed countries stand to loose.

\section{Insert Table 3}

Agricultural trade liberalisation has its impact on the market access positions of different economies of the world. It is very likely that reduction of protection in developed countries may lead to declining domestic production to a large extent. The production gaps in these liberalising countries are likely to be supplied by efficient economies of the world. Depending upon the demand situation in different liberalising economies, the supplying countries are to restructure their production process to meet the demand of the importing countries. This may lead to sectoral relocation of resources in various supplying countries. Therefore, the liberalisation process is likely to affect production, exports and imports in all the regions including India. The data are summarised in Table 4. As this table shows, paddy, wheat, and other agriculture are the sectors in India where production would expand following liberalisation while there would be a fall in production in cereal grain sector and livestock sector. On the other hand, following realignment along the line of comparative 
advantage, production contract only in other agriculture sector in the rest of South Asia. Agricultural Production by and large declines in the developed countries.

Insert Table 4 
The results of the present exercise indicate that the global economy is likely to witness a surge in exports of agricultural products following liberalisation.

The impact of trade liberalisation on India's export potential is shown in Table 6. The surge in the export growth can be noticed in the various important product segments.

\section{Insert Table 6}

In sum, when protection is reduced world-wide, India's welfare improve due to interregional and intersectoral shifts in economic activity.

However, as our results suggest, India's agricultural expands due to opening up of opportunities. However, soil degradation increases with increased use of land. To what extent, the above result would change if we incorporate land degradation feedback mechanism in our analysis? In what follows, we have done the same incorporating the feedback mechanism as articulated above. To prepare these results, we have run a simulation on the modified model (incorporating land productivity effects), the policy shocks to the model are (a) complete elimination of agricultural tariff (a) 6.8\% reduction in land productivity for paddy, wheat, grain sectors, $5.55 \%$ reduction in land productivity in other agricultural sector.

The results of our analysis are shown in Table 7. As this table shows, India's welfare increases by US $\$ 342$ million instead on US $\$ 360$ million when land degradation effects is assumed to be zero. By and large, welfare for other countries does not display any perceptible change. The expanding agricultural sectors now show marginally lower increase in production.

\section{Insert Table 7}

In summary, the inclusion of land degradation in a global model enables a fuller welfare analysis of the effects of economic policy changes. We find that agricultural trade liberalisation reduces land productivity, but the effects are weak to negate the benefits of India's welfare from agricultural trade liberalisation.

\section{Concluding Remarks}


The inclusion of environmental effects in a global trade model provides a fuller welfare analysis of the effects of economic policy changes. However, our study indicates that effects on onsite productivity effects are too weak to negate the benefits of India's welfare from agreement of agriculture.

However, we have not accounted for non-marketed off-site effects of soil erosion, which also arises with trade liberalisation. To that extent, our study results only provide an under-estimation of the full impact.

Measuring the environmental impacts of economic policy reform is not an exact science, particularly given the paucity and uncertainty of such environmental data. However, transparent modelling opens issues to debate and seems an appropriate means of improving our understanding while helping to provide estimates of the order of magnitude involved, given incomplete information. This paper is a small attempt towards the same objective.

\section{References}

- Alpay, S. (2003) "How Can Trade Liberalisation Be Conducive To A Better Environment- Survey Of Literature," Presented at the Sixth Annual Conference on Global Economic Analysis, June, The Hague, The Netherlands.

- Barrett, S. (1991) "Optimal Soil Conservation and the Reform of Agricultural Pricing Policies," Journal of Development Economics, vol. 36, pp. 167-87.

- Biljlsma et al (1996) "Coastal Zones and Small Islands," in R.T.Watson, M.C. Zinyowera and R. H. Moses (ed.) Climate Change 1995: Impacts, Adaptations and Mitigations of climate Change: Scientific-Technical Analysis- Contribution of working Group I to the Second Assessment of the Intergovernmental Panel on climate Change. Cambridge:Cambridge University Press, pp. 289-324.

- Burniaux, Jean-Marc and Huey-Lin Lee (2003) "Modelling Land Use Changes in GTAP," Presented at the Sixth Annual Conference on Global Economic Analysis, June, The Hague, The Netherlands.

- Brandon, C. Hommann, K. and Kishore, N.M. (1995) "The Cost of inaction: Valuing the Economy wide Cost of Environmental Degradation in India" Proceedings of the UNU Conference on the Sustainable Future of the Global System, Tokyo, 16-18 Oct, 1995.

- Darwin, R. and Richard S.J. Toll (2001) "Estimates of the Economic Effects of Sea Level Rise,” Environmental and Resource Economics, vol. 19, pp.113-129.

- Darwin, R., Tsigas, M., Lewandrowski, J., Raneses, A. (1995) "World Agriculture and Climate Change- Economic Adaptations," Agricultural Economic Report No. 703, 
Natural Resources and Environment Division, Economic Research Service, United States Department of Agriculture, Washington DC, USA.

- Dinar, A., R. Mendelson, R. Evenson, J. Parikh, A. Sanghi, K. Kumar, J. McKinsey, S. Lonnergan (1998) "Measuring The Impact of Climate Change on Indian Agriculture", World Bank Technical Paper no. 402.

- Dixon, P., B. R. Parmenter, A.A. Powell and P.J. Wilcoxen (1992) Notes and Problems in Applied General Equilibrium Economics, Aamsterdam: North-Holland.

- Elbehri, A., Leetmaa, S. (2002) "How Significant Are Export Subsidies To Agricultural Trade? Trade And Welfare Implications Of Global Reforms," Presented at the 5th Annual Conference on Global Economic Analysis, Taipei.

- Evans, D. (2001) "Identifying Winners and Losers in Southern Africa from Global Trade Policy Reform: Integrating Findings from GTAP and Poverty Case Studies," Presented at the Fourth Annual Conference on Global Economic Analysis, University of Purdue, USA.

- FAO (1995). Impact of the Uruguay Round on Agriculture, Rome: Food and Agricultural Organization.

- Frohberg, K., G. Fisher and K. S. Parikh (1990), "Would Developing Countries Benefit from Agricultural Trade Liberalization in OECD Countries?" in I. Goldin and O. Knudsen (eds.), Agricultural Trade Liberalization: Implications for Developing Countries, Paris: OECD.

- Gulati, A. and A. Sharma (1995), "Agriculture under Gatt: What it Holds for India", Economic and Political Weekly, 30: 1857-63.

- Hamasaki, H., Truong, T.P. (2001) "The costs of green house gas emission reductions in the Japanese economy- An investigation using the GTAP-E model," GTAP Resource \# 599, www.gtap.agecon.purdue.edu.

- Hertel, T.W. (1999), "Agriculture and Non-agricultural Liberalisation in the Millennium Round," Paper presented at the Conference on Agriculture and the New Trade Agenda in the WTO 2000 Negotiations (TWO, Geneva, 1-2 October).

- Hertel, T.W. and W. Martin (2000), "Liberalizing Agriculture and Manufactures in a Millennium Round: Implications for Developing Countries", World Economy, 23 (4): 455-469.

- IMF and WB (2002), Market Access for Developing Country Exports - Selected Issues, September 26, International Monetary Fund and the World Bank, Washington DC.

- Kuik, O. (2003) "Climate Change Policies, Energy Security and Carbon Dependency: Trade-offs for the European Union in the Longer Term," Presented at the Sixth Annual Conference on Global Economic Analysis, June, The Hague, The Netherlands.

- Kumar, K.S., Parikh, J. (1996) "Potential Impacts of Global Climate Change on Indian Agriculture", Communicated to Global Environment Change, 1996. 
- Kumar, K.S, and Parikh, J. (1998) "Climate Change Impacts on Indian Agriculture", in Dinar, A., R. Mendelson, R. Evenson, J. Parikh, A. Sanghi, K. Kumar, J. McKinsey, S. Lonnergan (ed.) World Bank Technical Paper no. 402, Ch5.

- Lonergan, Steve (1998) "Climate Warming and India," in Dinar, A., R. Mendelson, R. Evenson, J. Parikh, A. Sanghi, K. Kumar, J. McKinsey, S. Lonnergan (ed.) Measuring the Impact of Climate Change on Indian Agriculture, World Bank Technical Paper no. 402, Chapter 3.

- Mendelson, R., Nordhaus, W., and Shaw, D.G. (1994) "The Impact of Global Warming on Agriculture: A Ricardian Analysis", American Economic Review 84: 753-771.

- McKinsey, J.W.; Evenson, R.E. (1998): “Technology-Climate Interactions: Was The Green Revolution in India Climate Friendly?" in Dinar, A., R. Mendelsolm, R. Evenson, J. Parikh, A. Sanghi, K. Kumar, J. McKinsey, S. Lonnergan (ed.) Measuring the Impact of Climate Change on Indian Agriculture, World Bank Technical Paper no. 402, Chapter 6.

- Mohanty, S.K., Sanjib Pohit ans Saikat Sinha Roy (2006) "WTO Agreement on Agriculture, Liberalisation in Select Industrialised Countries, and Implications for Developing Countries: A CGE Modelling Analysis, “ presented in International Conference on International Trade, 2-3 January, Jadavpur University, Kolkata.

- Moutsatsos, D. (2000), “The Uruguay Round Agreement on Agriculture: Issues and Perspectives", in S. Bilal and P. Pezaros (eds.), Negotiating the Future of Agricultural Policies: Agricultural Trade and the Millennium WTO Round, The Hague: Kluwer Law International.

- Ministry of Rural Development, Department of Land Resources and National Remote Sensing Agency, (2000) Wastelands Atlas of India.

- Miranowski, J.A. (1984) "Impacts of Productivity Loss on Crop Production and Management in a Dynamic Economic Model" , American Journal of Agricultural Economics, 66, 61-71.

- Ninan , K.N. (2002) "Watershed Development programs in India: A Review" Paper Presented at the 12th ISCO Conference, Beijing, 2002.

- Parikh, K.S. (1989) "An Operational Measureable definition of Sustainable Development", Indira Gandhi Institute of Development Research, Discussion paper No.21.

- Parikh, K.S. and Upal Ghosh (1991) "Natural Resource Accounting for Soils: towards an Empirical Estimate of Costs of Soil Degradation in India" Indira Gandhi Institute of Development Research Discussion Paper No.48. 
- Pohit, Sanjib (1997) "The Impact of Climate Change on India's Agriculture: Some Preliminary Observations," Proceeding of the 20th International Conference of the International Association for Energy Economics, 22-24th January, Delhi, India.

- Pohit, Sanjib (2001), Agricultural Trade Liberalisation under GATT and Economic Reforms in India: A CGE Modelling Exercise, NCAER, New Delhi.

- Randhir, T.O., Hertel, T. W. (1999) “Trade Liberalisation As A Vehicle For Adapting To Global Warming," GTAP Working Paper No. 09, www.gtap.agecon.purdue.edu.

- Reilly, John, Peter H. Stone, Chris E. Forest, Mort D. Webster, Henri D. Jacoby and Ronald G. Prinn, (2001) "Uncertainty and Climate Change Assessments", GTAP Resource \# 1147, www.gtap.agecon.purdue.edu.

- Reilly, J. and Hohmann, N. (1993) "Climate Change and Agriculture: the Role of International Trade," American Economic Review, vol. 83, pp. 306-312.

- Repetto, P., W. Magrath, M. Wells, C. Beer and F. Rossini (1989) Wasting Assets: National Resources in the National Income Accounts, Washington D. C.: World Resources Institute.

- Rosegrant, M.W. and C. Ringler (1997) "Environmental and Resource Policies: Implications for Global Food Markets," Washington, DC: International Food Policy Research Institute, January.

- Repetto R, M. Wells, C. Beer and F. Rossini, (1987) Natural Resource Accounting for Indonesia, World Resource Institute, Washington D.C.

- Rosenzweig, C., Parry, M., Frohberg, K. and Fisher, G. (1993) "Climate Change and World Food Supply," Research report no. 3, Environmental Change Unit, University of Oxford, Oxford (U.K.).

- Sanghi, A., Mendelson, R., and Dinar, A. (1998) "The Climate Sensitivity of Indian Agriculture," in Dinar, A., R. Mendelsolm, R. Evenson, J. Pariskh, A. Sanghi, K. Kumar, J. McKinssey, S. Lonnergan (ed.) Measuring The Impact of Climate Change on Indian Agriculture, World Bank Technical Paper no. 402, chapter 4.

- Scherr, S.J. and S. Yadav (1996) "Land Degradation in the Development world: Implications for Food, Agriculture, and the Environment to 2020," IFPRI Food Agriculture, and the Environment Discussion Paper No. 14, Washington, DC: International Food Policy Research Institute, May.

- Storm, S. (1997), “Agriculture Under Trade Policy Reform: A Quantitative Assessment for India," World Development, 25 (3).

- Strutt, A. (1998) "Trade Liberalisation and Land Degradation In Indonesia," ACIAR Indonesia Research Project, working paper, no. 98.06, Univ. of Waikato, New Zealand. 
- Strutt, A., Anderson, K. (1998a) "Will Trade Liberalization Harm the Environment? The Case of Indonesia to 2020," Seminar paper 98-04, Center for International Economic Studies, Univ. of Adelaide, Australia.

- Strutt, A., Anderson, K. (1998b) "Will Uruguay Round and APEC Trade Liberalization harm the environment in Indonesia?" ACIAR Indonesia Research Project, working paper, no. 98.02, Univ. of Waikato, New Zealand.

- Sehgal J. . and Abrol, I.P. (1994) Soil Degradation in India: Status and Impact, Oxford and IBH Publishing Co.

- Singh Gurmel, Ram Babu, Pratap Narain, L.S. Bhushan and I.P. Abrol (1992) "Soil Erosion Rates in India", Journal of Soil and Water Conservation 47 (1), 9799.

- Truong, Truong and Huey-Lin Lee (2003) “GTAP-E Model and the 'new' CO2 Emissions Data in the GTAP/EPA Integrated Data Base - Some Comparative Results," Presented at the Sixth Annual Conference on Global Economic Analysis, June, The Hague, The Netherlands.

- Tsigas, M.E., Frisvold, G. B. and Kuhn, B. (1997) "Global Climate Change and Agriculture," in Global Trade Analysis: Modelling and Applications, ed. T.W. Hertel (Cambridge University Press, Cambridge, chapter 11, pp. 280-304.

- Tsigas, M.E., Gray, D., Hertel, T.W. (2002) "How To Assess The Environmental Impacts Of Trade Liberalisation," Presented at the 5th Annual Conference on Global Economic Analysis, Taipei.

- UNCTAD/UNDP/ WIDER (1990), Agricultural Trade Liberalisation in the Uruguay Round: Implications for Developing Countries, UNCTAD/ITP/48, New York: United Nations.

- UN-ESCAP (1995), "Benefits and Challenges Facing Asia-Pacific Agricultural Trading Countries in the Post-Uruguay Round Period", Studies in Trade and Investment 11, New York: United Nations.

- Vellinga, P. and S.P. Leatherman (1989) "Sea Level Rise, Consequences and Policies," Climate Change, vol. 15, pp. 175-189.

- Warrick,R. A., C. Le Provost, M.F. Meier, J. Oerlemans and P. L. Woodworth (1996) "Changes in Sea Level,", in J.T. Houghton, L.G. Meirro Filho, B.A. Callander, N. Harris, A. Kattenberg and K. Maskell (ed.) Climate Change 1995: The Science of Climate Change-Contribution of working Group I to the Second Assessment of the Intergovernmental Panel on climate Change. Cambridge:Cambridge University Press, pp. $359-405$.

- World Bank (1992) World Development Report, New York: Oxford University Press. 
- World Resources Institute (1994) World Resources 1994-95, New York: Oxford University Press.

- Zheng, Y., Ma, G.: Impact Of Carbon Tax And Reduced CO2 Discharge On Chinese Economy: A Static CGE Analysis, unpublished.

- Mc Connell, K.E. (1983) "An Econometric Model of Soil Conservation" American Journal of Agricultural Economics, 65: 83-89. 
Table 1 Soil Degradation Statistics ( area in million ha)

\begin{tabular}{|c|c|c|c|c|}
\hline \multirow[t]{2}{*}{ Type } & \multicolumn{2}{|c|}{ Ministry of Agri. \& co-operation } & \multicolumn{2}{|c|}{ Sehgal and Abrol } \\
\hline & 1980 & 1985 & $1994 \$$ & 1997@ \\
\hline Soil erosion* & 150.0 & 141.2 & 162.4 & 167.0 \\
\hline Saline and Alkaline soil & 8.0 & 9.4 & 10.1 & 11.0 \\
\hline waterlogging & 6.0 & 8.5 & 11.6 & 13.0 \\
\hline Shifting cultivation & 4.4 & 4.9 & & 9.0 \\
\hline Total degradation & 168.4 & 175.1 & 175.0 & 187.8 \\
\hline
\end{tabular}

* This includes both wind and water erosion, but water erosion accounts for more than $90 \%$.

\$Sehgal and Abrol(1994)@TERI Report

Table 2 Sectors \& Regions

Sectors: The Aggregated Structure

\begin{tabular}{|lll|}
\hline No. & Code & Description of sectors \\
\hline 1 & PDR & Paddy \\
\hline 2 & WHT & Wheat \\
\hline 3 & GRO & Cereal Grains \\
\hline 4 & OAG & Other Agriculture \\
\hline 5 & LIF & Livestock \& Forestry \\
\hline 6 & FOOD & Food \\
\hline 7 & MNL & Minerals \\
\hline 8 & NFD & Textiles, Apparel and Leather products \\
\hline 9 & MNF & Manufacturers \\
\hline 10 & SER & Services et al \\
\hline
\end{tabular}

Regions: The Aggregated Structure

\begin{tabular}{|lll|}
\hline No. & Code & Description of regions \\
\hline 1 & IND & India \\
\hline 2 & OSA & Other South Asia comprising of Bangladesh, Sri Lanka \& Rest of South Asia \\
\hline 3 & AUN & Australia \& New Zealand \\
\hline 4 & USA & USA \\
\hline 5 & CAN & Canada \\
\hline 6 & JPN & Japan \\
\hline 7 & OEA & Other East Asia comprising of China, Hong Kong, Taiwan, Korea \\
\hline 8 & SEA & Six Southeast Asia economies comprising of Indonesia, Malaysia, Philippine, \\
\hline & & Singapore, Thailand, Vietnam \\
\hline 9 & EU & European Union \\
\hline 10 & ROW & All other regions \\
\hline
\end{tabular}


Table 3: Implication of Agricultural Trade Liberalisation on Regional Welfare Gains (Equivalent Variation)

\begin{tabular}{|l|c|l|c||}
\hline \multicolumn{1}{|c|}{$\begin{array}{c}\text { Economies/ } \\
\text { Regions }\end{array}$} & $\begin{array}{c}\text { Welfare (US \$ } \\
\text { Million) }\end{array}$ & \multicolumn{1}{|c||}{$\begin{array}{c}\text { Economies/ } \\
\text { Regions }\end{array}$} & $\begin{array}{c}\text { Welfare (US \$ } \\
\text { Million) }\end{array}$ \\
\hline India & 360.0 & Japan & 19.6 \\
\hline Other SA & 12.3 & Other East Asia & 3.9 \\
\hline AUN & 14.3 & South East Asia & -13.2 \\
\hline USA & -12.0 & EU & -1.5 \\
\hline Can & -5.6 & ROW & 30.2 \\
\hline \hline
\end{tabular}

Table 4: Implication of Agricultural Trade Liberalisation: By Production (\% Change)

\begin{tabular}{|c|c|c|c|c|c|c|c|c|c|}
\hline REG & IND & OSA & AUN & USA & $\mathrm{CAN}$ & JPN & OEA & SEA & EU \\
\hline PDR & 0.73 & 0.02 & -1.94 & -2.34 & -0.82 & -0.11 & -0.04 & -0.02 & -11.13 \\
\hline WHT & 0.07 & 0.06 & -0.08 & 0.02 & -0.07 & -0.17 & 0.01 & 0.02 & -0.06 \\
\hline GRO & -0.12 & 0.01 & -0.09 & 0.01 & -0.04 & -0.01 & -0.01 & 0.06 & -0.03 \\
\hline $\mathrm{OAG}$ & 1.05 & -0.25 & 0.30 & -0.21 & -0.18 & -0.08 & -0.05 & -0.09 & -0.17 \\
\hline LIF & -0.21 & 0.03 & -0.05 & 0.02 & 0.00 & 0.01 & 0.01 & 0.03 & 0.01 \\
\hline
\end{tabular}

Table 5: Implication of Agricultural Trade Liberalisation on World Export (\% Change )

\begin{tabular}{|c|c|}
\hline Sector & Value of Trade (\% Change \\
\hline PDR & 0.2047 \\
\hline WHT & 0.1129 \\
\hline GRO & 0.0319 \\
\hline $\mathrm{OAG}$ & 0.0616 \\
\hline LIF & 0.035 \\
\hline
\end{tabular}

Table 6: Implication of Agricultural Trade Liberalisation on India's Export (\% Change )

\begin{tabular}{|l|l|}
\hline Commodity & Exports (\% Change) \\
\hline PDR & 89.55 \\
\hline WHT & 88.37 \\
\hline GRO & 96.28 \\
\hline OAG & 56.60 \\
\hline LIF & -5.89 \\
\hline
\end{tabular}

Table 7: Impact of Agricultural Liberalization in presence of Land Degradation

\begin{tabular}{|l|c|c|c|c|c|}
\hline Welfare (US \$ Million) & \multicolumn{5}{|c|}{ US \$ 341.59 } \\
\hline & PDR & WHT & GRO & OAG & LIF \\
\hline Production (\% Change) & 0.68 & 0.05 & -0.13 & 0.99 & -0.20 \\
\hline
\end{tabular}

